\title{
Performance, carcass traits, meat quality and economic analysis of feedlot of young bulls fed oilseeds with and without supplementation of vitamin E
}

\section{Otávio Rodrigues Machado Neto ${ }^{1}$, Márcio Machado Ladeira ${ }^{2}$, Mário Luiz Chizzotti ${ }^{2}$, André Mendes Jorge ${ }^{3}$, Dalton Mendes de Oliveira ${ }^{1}$, José Rodolfo Reis de Carvalho ${ }^{1}$, Julimar do Sacramento Ribeiro 4}

\author{
1 Programa de Pós-Graduação Stricto Sensu em Zootecnia - DZO/UFLA \\ 2 DZO/UFLA. Researcher from CNPq and INCT-CA. \\ ${ }^{3}$ FMVZIUNESP. Researcher from CNPq. \\ ${ }^{4}$ Universidade Federal de Alagoas.
}

\begin{abstract}
The objective of this research was to evaluate average daily gain (ADG), carcass traits, meat tenderness and profitability of keeping cattle fed different oilseeds and vitamin E in feedlot. A total of 40 Red Norte young bulls with initial average body weight of $339 \pm 15 \mathrm{~kg}$ were utilized. The experimental design was completely randomized in a $2 \times 2$ factorial arrangement. The experiment lasted 84 days and experimental diets presented soybeans or cottonseeds as lipid sources associated or not to daily supplementation of 2,500 UI vitamin E per animal. The concentrate:roughage ratio was 60:40. Diets had the same amount of nitrogen (13\% CP) and ether extract (6.5\%). The data were analyzed by means of statistical software SAS 9.1. Neither vitamin supplementation nor lipid source affected ADG. There was no interaction between lipid source and vitamin supplementation for the variables studied. The inclusion of cottonseed reduced the carcass yield. There was no effect of diets on hot and cold carcass weights or prime cuts. The inclusion of cottonseed reduced the backfat thickness. No effect of experimental diets on the rib-eye area was observed. There was no effect of lipid source or vitamin supplementation on meat tenderness, which was affected, however, by ageing time. Diets with soybeans presented higher cost per animal. The utilization of soybean implied reduction of the gross margin (R \$ 59.17 and R\$ 60.51 for diets based on soy with and without supplemental vitamin, respectively, vs. R\$ 176.42 and R\$ 131.79 for diets based on cottonseed). The utilization of cottonseed enables improvement of profitability of feedlot fattening, in spite of negatively affecting some carcass characteristics.
\end{abstract}

Key Words: cottonseed, ageing, profitability, soybean

\section{Introduction}

Currently, in Brazil, the activity of feedlot rearing has had great importance in intensive beef cattle production systems. In 2009 only, more than 3 million animals were confined in Brazil (Millen et al., 2009). Such number is a result of the increase in the number of feedlot activities and also the number of animals housed per feedlot. However, with the increasing number of feedlot animals per fattening cycle, there may be need to increase the energetic content of the diets, once the restriction of the area available to the production of roughages may not allow high inclusion of this ingredient. In view of this, strategies must be adopted to minimize the risks of incidence of ruminal acidosis.

The utilization of lipid sources such as soybean in the feeding of cattle enables decrease in the starch content of diets, thus collaborating to improvement in the ruminal environment. The cotton seed, in turn, in addition to having lipid content similar to soybean, presents high content of fiber, which can collaborate to reduction in the incidence of digestive disorders in feedlot cattle. Furthermore, the inclusion of oilseeds in diets for feedlot animals promotes greater weight gain rates (Maddock et al., 2006).

Cranston et al. (2006) conducted three experiments utilizing cottonseed in diets for finishing cattle. According to the authors, the seed of cotton or the byproducts of its processing can be utilized without side effects on performance and carcass characteristics. However, the results obtained with the utilization of this feedstuff are highly dependent on the inclusion level due to its ether extract content.

According to Secrist et al. (1997), cattle that have just arrived at the feedlot are usually under stressful situations, so measures should be taken in order to avoid this problem. Moreover, Hill \& Williams (1993) reported that daily supplementation of 200 UI vitamin E per animal can increase the daily weight gain, especially if animals are under stressful conditions.

Therefore, the objective of this study was to evaluate performance, carcass characteristics and tenderness of 
meat from cattle fed soybeans or cottonseeds, associated or not to supplementation of vitamin E. Afterwards, a study of the economic viability of the diets utilized was carried out.

\section{Material and Methods}

A total of 40 young bulls of the Red Norte breed with average age of 20 months and initial average weight of $339 \pm 15 \mathrm{~kg}$ were used. Before the onset of the experiment, animals were weighed and treated against ecto and endoparasites.

The design was completely randomized, in a $2 \times 2$ factorial arrangement, with four treatments and ten replicates per treatments. Experimental diets were balanced according to the NRC (2000) to have the same amount of nitrogen, with the corn silage as roughage and two types of concentrate: one containing ground soybean and another with ground cottonseed, as lipid sources (Table 1). Oilseeds were ground aiming to increase the net energy for maintenance (NEm) and the net energy for gain (NEg) of diets, as reported by Maddock et al. (2006). Besides, it has been reported that grinding of cottonseed promotes increase in the total digestibility of organic matter and also of crude protein (Pires et al., 1997). Half of the animals which received each concentrate were supplemented with 2,500 UI Vitamin E/day, during the whole experimental period; prior to the addition of this ingredient to the concentrates, pre-mixing with corn and soybean meal was done.

For so, the following treatments were evaluated: concentrate containing soybean, without supplementation

Table 1 - Ingredients and chemical composition of experimental diets, based on the total dry matter

\begin{tabular}{|c|c|c|c|c|}
\hline Ingredients & SB & SBE & CS & CSE \\
\hline Corn silage $(\mathrm{g} / \mathrm{kg})$ & 400 & 400 & 400 & 400 \\
\hline Ground soybean (g/kg) & 200 & 200 & - & - \\
\hline Soybean meal (g/kg) & - & - & 30 & 30 \\
\hline Cottonseed (g/kg) & - & - & 240 & 240 \\
\hline Ground corn grain $(\mathrm{g} / \mathrm{kg})$ & 382 & 382 & 312 & 312 \\
\hline Mineral mixture $^{1}(\mathrm{~g} / \mathrm{kg})$ & 18 & 18 & 18 & 18 \\
\hline Basal vitamin E (UI/day) & 281 & 275 & 394 & 386 \\
\hline Supplemental vitamin E (UI/day) & - & 2500 & - & 2500 \\
\hline \multicolumn{5}{|l|}{ Chemical composition (g/kg) } \\
\hline Crude protein & 129 & 129 & 127 & 127 \\
\hline Ether extract & 64.8 & 64.8 & 65.6 & 65.6 \\
\hline NDF & 270 & 270 & 360 & 360 \\
\hline $\mathrm{NFC}^{2}$ & 460 & 460 & 400 & 400 \\
\hline $\mathrm{TDN}^{2}$ & 820 & 820 & 770 & 770 \\
\hline
\end{tabular}

${ }^{1}$ Guaranteed levels per kg of product: Ca - 170 g; Co - 15 mg; Cu - 396 mg; P 31 g; I - 29 mg; Mg - 15 g; Mn - 515 mg; Se - 5.4 mg; Na - 155 g; Zn - 2,000 mg. 2 Calculated according to the NRC (2001).

SB - concentrate containing soybean; SBE - SB + Vitamin E; CS - concentrate containing cottonseed; CSE - CS + Vitamin E.; NDF - neutral detergent fiber; NFC - non-fibrous carbohydrates; TDN - total digestible nutrients. of vitamin E; concentrate containing soybean, with supplementation of vitamin $\mathrm{E}$; concentrate containing cottonseed without supplementation of vitamin; and concentrate containing cottonseed, with supplementation of vitamin E. The level of vitamin E utilized in this study followed the recommendations of Yang et al. (2002) for feedlot cattle.

The experiment lasted 84 days, preceded by 28 days for adaptation to facilities and diets. At every fifteen days, samples of the feeds were collected for analyses of chemical composition. Animals were weighed at the beginning of the experiment and every 28 days, after fasting for 16 hours. Refusals of the diet supplied were weighed daily, before the first feeding in the morning, for determination of average dry matter intake of each treatment.

The animals were confined in collective stalls with an area of $30 \mathrm{~m}^{2}$ per animal, separated according dietary treatments. The feedlot facilities had a compacted dirt floor, the area close to the feeder was covered with concrete and had wire divisions. The collective drinkers were located at the division of two stalls and vinyl type feeders were used, placed transversely on the upper part of the pens. Diets were supplied twice daily, at 7h00 and 15h00, in the form of total feed, and were adjusted so as to keep refusals at around $5 \%$ of the total supplied.

Analyses of dry matter (DM), organic matter (OM), crude protein (CP) and ether extract (EE) of feeds were performed according to the AOAC (1990).

Concentrations of neutral detergent fiber (NDF) were analyzed according to Goering \& Van Soest (1970) and NDF of concentrates, according to procedure described by Van Soest et al. (1991). Subsequently, for the determination of NDF corrected for ash and protein (NDFap), the contents of neutral detergent insoluble nitrogen (NDIN) and mineral matter in the neutral detergent insoluble fractions were analyzed. The TDN content of diets was estimated according to the equation suggested by the NRC (2001). Non-fibrous carbohydrates were determined by the equation $\mathrm{NFC}=[100-(\% \mathrm{CP}+\% \mathrm{NDF}+\% \mathrm{EE}+\%$ Ash $)]$, according to the NRC (2001), but utilizing NDF corrected for ash and protein (NDFap).

Slaughtering of animals was conducted in commercial slaughterhouse, utilizing the technique of brain concussion and section of the jugular vein, followed by removal of hides and evisceration. Carcasses were identified, washed and split in two halves, which were then individually weighed and taken to cold chamber for approximately 24 hours at $1{ }^{\circ} \mathrm{C}$. After this period they were weighed once again and divided in forequarter, hindquarter and spare ribs. 
Measurements performed on the carcass after chilling were: total cold carcass yield, total weight of cold carcass and prime cuts, rib-eye area and backfat thickness. The ribeye area was measured between the 12th and 13th ribs, with the aid of a checkered grid. Backfat thickness was also measured between the 12 th and 13 th ribs at $3 / 4$ of the medial border on the left side of the cold carcass on the longissimus dorsi, with the aid of a digital caliper rule.

At deboning, 24h post mortem, samples of the muscle longissimus dorsi of the left half carcass were collected for determination of shear force. These samples were vacuumpacked in polyethylene bags and subjected to four maturation times at $2{ }^{\circ} \mathrm{C}(0,7,14$ and 21 days).

Cooking loss was determined according to Amasa (1978). Samples were baked in the form of steak (2.54 thickness) in pre-heated in oven at $170{ }^{\circ} \mathrm{C}$ until reaching temperature of $70^{\circ} \mathrm{C}$ in the geometric center, controlled by thermocouples. After 60 minutes, 6 sub-samples of each steak parallel to the muscle fibers were taken, according to Wheeler et al. (1995). Shear force was measured individually, so that each sub-sample was placed perpendicularly to the muscle fibers on Warner-Bratzler cell with $1.016 \mathrm{~mm}$ blade coupled to texturometer MTA.TX.plus (Stable Micro Systems Ltd., Vienna Court, UK). Maximum force for each sub-sample was recorded at the curve of software Texture Expert and means of values in times 0, 7,14 and 21 maturation days were used at the statistical analysis.

The costs with feeding were calculated considering the prices of each ingredient practiced in the first semester of 2009. The values of the feedstuffs utilized (Brazilian real R \$/t) were: 80.00 (corn silage); 747.00 (soy); 300.00 (corn); 300.00 (cottonseed); 681.00 (soybean meal) and 1315.00 (mineral mix). For the calculation of total operational cost, it was considered that the cost with feeding represented $87 \%$ of the total cost of the activity (Lopes et al., 2011). The gross margin with animal sales was calculated by subtracting the revenue with animal sales from the total operational cost of all feedlot period. For the calculation of the revenue obtained in arrobas ( 1 arroba $=15 \mathrm{~kg}$ ) of carcass, the daily weight gain during the feedlot period was multiplied by the carcass yield. The gross margin was also calculated considering the opportunity generated with the pasture cleared during feedlot. In this situation, a simulation was done, in which the time necessary to achieve, on pasture, the weight gain obtained in feedlot was considered. It was considered that the weight gain of animals on pasture receiving protein supplementation ( $0.5 \%$ live weight - LW) would be about $600 \mathrm{~g} /$ head/day. The total gross margin corresponded to the sum of the gross margin with the sale of the meat plus the revenue estimated with the rent of the pasture cleared because of the feedlot. The cost of R $\$ 25.00$ per animal per month in pasture regimen subjected to supplementation was taken into consideration.

The experimental design utilized was completely randomized in a $2 \times 2$ factorial arrangement. The statistical model utilized was:

Yijk $=\mu+\mathrm{Li}+\mathrm{Vj}+(\mathrm{LV}) \mathrm{ij}+$ eijk

Yijk = observation concerning animals subjected to the $i$-th lipid source ( $i=1-2)$ and $j$-th supplementation with vitamin $\mathrm{E}$ (1-2); $\mu$ = overall mean; $\mathrm{Li}=$ effect of lipid source (cottonseed or soybean); $\mathrm{Vj}$ = effect of supplementation with vitamin $\mathrm{E}$ (with and without it); (LV)ij = effect of interaction between lipid source and vitamin E; eijk = error inherent to each observation.

Data from performance and carcass characteristics were submitted to variance analysis utilizing the feature PROC GLM of the statistical software SAS (Statistical Analysis System, version 9.1), taking $\alpha=0.05$. Data from shear force and cooking loss were submitted to variance analysis utilizing the feature PROC MIXED from statistical software SAS (Statistical Analysis System, version 9.1) as well.

\section{Results and Discussion}

No effect of supplementation of lipid sources utilized was verified $(\mathrm{P}>0.05)$ on average daily weight gain (ADG) of animals during all the periods analyzed (Table 2). The similar performance to the animals subjected to different diets can be explained by the similar dry matter intake between diets. The data from intake were discussed based on descriptive analysis, once the dry matter intake was measured per lot, and cannot be subjected to statistical test. In spite of the higher NDF content and lower energy content of the diets with cottonseed, these differences were not sufficient to influence animal performance. The similar performance may have been a consequence of the dry matter intake, which was also similar for animals subjected to the different diets. However, TDN values were estimated by means of use of prediction equations of the NRC (2001), and it is important to emphasize that had these values been measured daily, the differences observed might have been null.

According to Millen et al. (2009), cottonseed is the main byproduct of agro-industry utilized in diets for feedlot cattle in Brazil, and $45.2 \%$ of these entrepreneurships have this byproduct as first option. The big interest in the utilization of cottonseed is the consequence of its chemical characteristics, once it gathers high concentrations of fiber, protein and fat in only one ingredient, which, according to Carnston et al. (2006), can collaborate to reduction in the 
Table 2 - Initial and final body weight and performance of young bulls fed soybeans (SB), soybean + vitamin E (SBE), cottonseed (CS) and cottonseed + vitamin E (CSE)

\begin{tabular}{|c|c|c|c|c|c|c|c|c|}
\hline \multirow[t]{2}{*}{ Items } & \multicolumn{4}{|c|}{ Diets } & \multirow[t]{2}{*}{ SEM } & \multicolumn{3}{|c|}{ Probability } \\
\hline & SB & SBE & CS & CSE & & $\mathrm{L}$ & V & $\mathrm{L} \times \mathrm{V}$ \\
\hline Initial weight (kg) & 343 & 343 & 327 & 340 & 15.67 & 0.850 & 0.732 & 0.864 \\
\hline Final weight (kg) & 457 & 461 & 450 & 455 & 15.10 & 0.961 & 0.753 & 0.940 \\
\hline DM intake (kg/day) & 10.6 & 10.4 & 10.5 & 10.3 & - & - & - & - \\
\hline ADG (kg/day; 0-28 days) & 1.94 & 1.87 & 2.03 & 1.75 & 0.110 & 0.321 & 0.330 & 0.664 \\
\hline ADG (kg/day; 0-56 days) & 1.78 & 1.86 & 1.69 & 1.57 & 0.080 & 0.156 & 0.204 & 0.771 \\
\hline ADG (kg/day; 0-84 days) & 1.39 & 1.42 & 1.50 & 1.40 & 0.070 & 0.683 & 0.364 & 0.880 \\
\hline Feed efficiency & 0.131 & 0.136 & 0.142 & 0.136 & - & - & - & - \\
\hline
\end{tabular}

L - effect of lipid source; V - effect of vitamin supplementation; $\mathrm{L} \times \mathrm{V}$ - interaction; ADG - average daily gain; SEM - standard error of the mean.

cost of diets. The average inclusion level of cottonseed in diets for feedlot animals in Brazil is of 15\%, reaching maximum level of $27.5 \%$ (Millen et al., 2009), which is a value close to that utilized in the present study (24\% of the dietary DM).

In view of the results observed for performance and feed efficiency (Table 2), it is possible to conclude that the concentration of ether extract in diets for ruminants can be superior to $5-6 \%$ of the DM, which is a level considered maximum in some publications (NRC, 2000; Valadares Filho et al., 2002). Recent studies indicate the possibility of increase in the concentration of lipids in diets for ruminants to levels considerably above 6\%. According to Vasconcelos \& Galyean (2007), the average level of ether extract of diets for feedlot animals in the United States is 7.6\%. Gunn et al. (2009) conducted an experiment with utilization of increasing levels of distillers grains, in which diets with greater content of this byproduct presented $9.2 \%$ ether extract and the average daily gain observed was similar to that of the present experiment (1.43 kg/day). Once the distillers grain is a source of fat partially protected from ruminal biohydrogenation, as well as the cottonseed and the soybean, one can infer that the increase in the concentration of such ingredients might not result in negative effects on animal performance, depending on the level of roughage in the diet utilized. The increase in the lipid content of diets with high content of roughage, such as that of the present experiment (40\% DM) can depress the digestion of dietary fiber.

No effect of supplementation with vitamin E was verified on the variables related to animal performance ( $P>0.05$; Table 2). Positive effect of supplementation with vitamin $\mathrm{E}$ on these characteristics could be expected, once supplementation of this nutrient can improve the immune system of animals (Peplowski et al., 1980; Reddy et al., 1986; Nemec et al., 1994). Hill \& Williams (1993) reported that daily supplementation of 200 UI vitamin E can increase daily weight gain, especially if animals are under stressful situations. Therefore, in the conditions of this trial, the ingestion of vitamin E was probably satisfactory and animals were not under stress.

As for the quantitative characteristics of the carcass, decrease of carcass yield was observed $(\mathrm{P}<0.05)$ when there was inclusion of cottonseed in the diet (Table 3 ). Similar results have been reported by Oliveira (2010), who worked with Nellore steers receiving diets similar to this experiment and observed carcass yield of $56.1 \%$ for animals fed soybean and $54.1 \%$ for animals subjected to the diet with cottonseed. Likewise, Pesce (2008) observed decrease in carcass yield when subjecting animals to diets with 10 or $20 \%$ cottonseed. The likely explanation for reduction in the carcass yield is due to the fact that the greater NDF

Table 3 - Quantitative characteristics of the carcass of young bulls fed soybean (SB), soybean + vitamin E (SBE), cottonseed (CS) and cotton seed + vitamin E (CSE)

\begin{tabular}{|c|c|c|c|c|c|c|c|c|}
\hline \multirow[t]{2}{*}{ Items } & \multicolumn{4}{|c|}{ Diets } & \multirow[t]{2}{*}{ SEM } & \multicolumn{3}{|c|}{ Probability } \\
\hline & SB & SBE & CS & CSE & & L & V & $\mathrm{L} \times \mathrm{V}$ \\
\hline HCW (kg) & 252 & 258 & 243 & 248.9 & 9.34 & 0.331 & 0.960 & 0.580 \\
\hline FQW (kg) & 99.9 & 103 & 92.7 & 98.3 & 4.05 & 0.157 & 0.765 & 0.885 \\
\hline HQW (kg) & 113 & 115 & 109 & 108 & 3.97 & 0.155 & 0.724 & 0.961 \\
\hline SPRW (kg) & 36.8 & 37.1 & 32.2 & 33.4 & 1.57 & 0.110 & 0.770 & 0.783 \\
\hline SFT (mm) & 3.60 & 3.76 & 3.04 & 3.26 & 0.26 & 0.050 & 0.920 & 0.904 \\
\hline CY (\%) & 55.1 & 55.8 & 53.8 & 54.6 & 0.53 & 0.021 & 0.960 & 0.947 \\
\hline
\end{tabular}

L - effect of lipid source; V - effect of vitamin supplementation; L $\times \mathrm{V}$ - interaction. HCW - hot carcass weight, CCW - cold carcass weight; FQW - forequarter weight; HQW - Hindquarter weight; SPR - spare ribs weight; REA - rib-eye area; SFT - backfat thickness; CY(\%) - carcass yield; SEM - standard error of the mean. 
content in diets with cottonseed caused bigger volume in the digestive tract and, consequently, greater weight of viscera (Cranston et al., 2006).

No effect of diets on hot carcass weight was verified ( $\mathrm{P}>0.05)$; in all the situations it could be observed that its value was above $240 \mathrm{~kg}$, which is considered the minimum for the processing costs of carcass by the slaughterhouse industry not to become excessively high. Likewise, no effect on diets was observed on the variable cold carcass weight ( $\mathrm{P}>0.05$ ). Costa et al. (2011) also did not observe effect of different levels of cottonseed ( $0,14,27$ and 34\% DM) in the diet on the hot carcass weight. However, HuertaLeidenz et al. (1991), in an experiment with crossbred Hereford-Angus cattle finished for a period of 56 days and subjected to diets with cottonseed at levels 0, 15 and 30\% dietary DM observed significant decrease in the weight of carcass and also rib-eye area at the level of $30 \%$ inclusion of cottonseed.

No effect of diets $(\mathrm{P}>0.05)$ was verified on the prime carcass cuts (forequarter, hindquarter and spare ribs). Once no effect of diets was observed on average daily weight gain or carcass weight, it was expected that no effects would be observed on these cuts. Restle et al. (2002), in an experiment with Red Angus young steers subjected to different slaughter weights, observed linear decrease in the relative weight of the spare ribs, which, according to Vaz (1999), is a result of greater fat deposition at this region. In the present experiment, hindquarter, forequarter and spare ribs cuts stood for, on average, $40.2,45.5$ and $14.2 \%$ of the cold carcass weight, respectively.

Decrease $(\mathrm{P}<0.05)$ in the backfat thickness in the carcass was observed in animals subjected to diets with cottonseed. Such behavior was reported by Costa et al. (2011), who observed linear reduction of the subcutaneous fat with increase in the level of cottonseed meal in the diets. However, Oliveira (2010) did not observe effect of cottonseed on the backfat thickness of Zebu steers. The decrease in the backfat thickness observed in the carcass of animals fed cottonseed can be a result of the lower energy concentration of the diets containing this feedstuff, once they represented $77 \%$ TDN, whereas the diets with soybean had $82 \%$. Therefore, there would be less energy available for the synthesis of subcutaneous fat.

The rib-eye area (REA) also was not affected by diets ( $\mathrm{P}>0.05)$ and similar results were observed by Pesce (2008) in an experiment with $20 \%$ inclusion of cottonseed in the dietary DM. According to Lucchiari Filho (2000), in order to achieve good meat cut yields in the carcass, the REA value must be approximately $29 \mathrm{~cm}^{2} / 100 \mathrm{~kg}$ carcass, which is close to the numbers found in the present study (Table 3). Regarding cooking losses (Figure 2), no effect of lipid source $(P>0.05)$, vitamin supplementation $(P>0.05)$, interaction of oilseed and vitamin supplementation $(\mathrm{P}>0.05)$ or interaction between days at maintenance and the other variables was verified. However, a trend towards increase in cooking loss over the maturation time $(\mathrm{P}<0.10)$ was verified, which is a result of alterations in the water holding capacity promoted by the maturation process. Reduction in the water holding capacity occurs when the muscle $\mathrm{pH}$ decreases, after the death of the animal, and it gets closer and closer to the isoelectric point of myofibrillar proteins, especially myosin $(\mathrm{pI}=5.4)$. According to Huff-Lonergan \& Lonergan (2005), when it happens, the electric charges of myofibrillar proteins tend to nullify and no longer bind to water. In addition to the $\mathrm{pH}$, other post-mortem events have an influence on the ability of the meat to retain water, such as the proteolysis exerted by the calpain system, which acts on important proteins of the cytoskeleton of the muscle fiber (Bilak et al., 1998), and the oxidation of myofibrillar proteins, which results in reduction in their functionality (Xiong \& Decker, 1995).

As for the shear force, no effect of lipid source $(\mathrm{P}>0.05)$, vitamin supplementation $(\mathrm{P}>0.05)$ or interaction between these variables $(\mathrm{P}>0.05)$ was verified (Tabela 4$)$. However, there was effect of maturation time (Figure 1 ) on this variable $(\mathrm{P}<0.01)$. Likewise, no effect of interaction $(\mathrm{P}>0.05)$ between maturation time and the other variables (lipid source, vitamin supplementation) was verified. Decrease in the values observed for shear force in function of ageing time can be explained by some changes in the structure of the muscle myofibrils, such as degradation of the Z-line of the sarcomere,

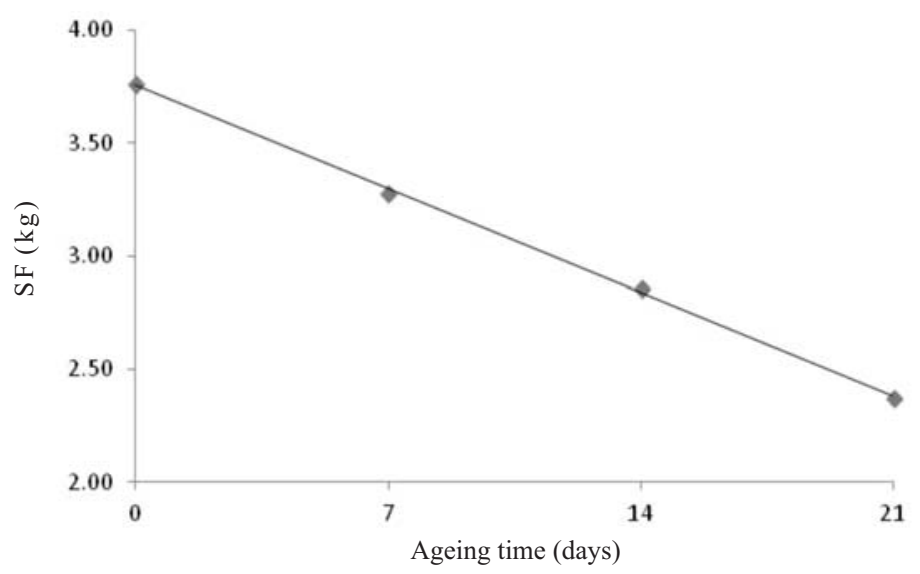

Figure 1 - Effect of maturation time on shear force (SF). 


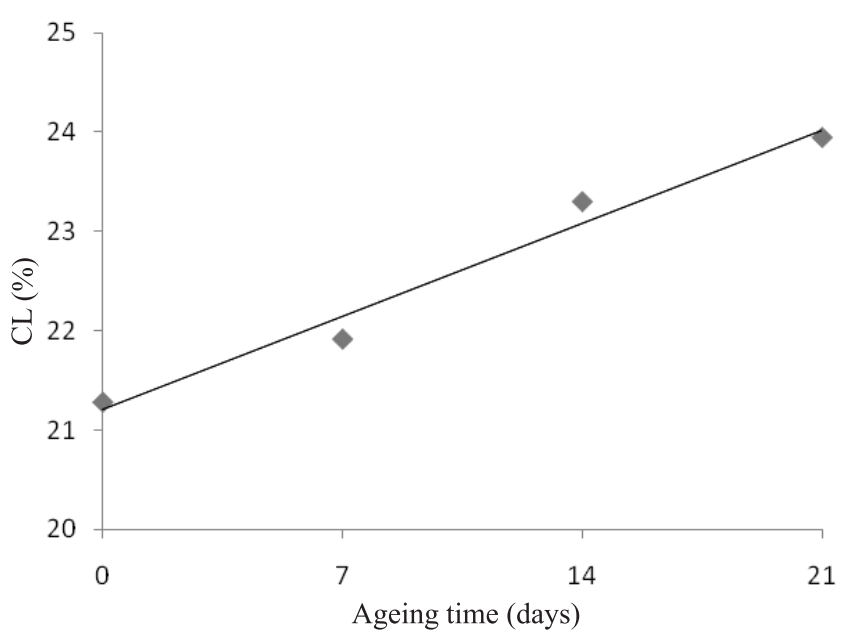

Figure 2 - Effect of ageing time (days) on cooking loss (CL, \%).

Table 4 - Estimates of regression parameters and coefficient of determination and probability value ( $\mathrm{P}$ value) for shear force and cooking loss

\begin{tabular}{lcccccc}
\hline & \multicolumn{2}{c}{ Intercept } & & \multicolumn{2}{c}{ Slope } & \\
\cline { 2 - 3 } Variable & Estimate & $\mathrm{P}$ value & & Estimate & $\mathrm{P}$ value & $\mathrm{r}^{2}$ \\
\hline Shear force & 3.75 & $<0.001$ & & -0.06 & $<0.001$ & 0.20 \\
Cooking loss & 21.20 & $<0.001$ & & 0.13 & $<0.001$ & 0.04 \\
\hline
\end{tabular}

and of other myofibrillar proteins (desmin, titin, nebulin and troponin $\mathrm{T}$ ), leading to myofibrillar fragmentation and simultaneous appearance of polypeptides, indicating the occurrence of proteolysis (Koohmaraie, 1994). Andrade et al. (2010) evaluated the effect of different maturation times $(0,7,14$ and 21 days) on meat tenderness of Red Norte cattle, observing similar values to those obtained in the present experiment. The absence of effect of diets on the meat shear force can be explained by the similar slaughter age of animals subjected to different treatments and also because diets had the same effect on post-mortem proteolysis. All the shear force values observed in the present experiment were below $4.5 \mathrm{~kg}$, which is well accepted as standard for tenderness according to Leme et al. (2002).

The diets containing soybeans were those which presented highest cost with feeding (Table 5); supplementation with vitamin E resulted in an increase of $\mathrm{R} \$ 0.15$ per animal/ day, or R\$12.60/animal for a feedlot period of 84 days. Considering that no positive effects of the addition of this vitamin were detected, its utilization may imply reduction in the profit margin of the feedlot operation.

The total cost per arroba produced in feedlot was quite superior to the value received per arroba at the slaughterhouse (Table 5). Thus, considering only the revenue obtained with the sale of carcasses and the intensive fattening as an isolate production system, feedlot was found to be an unviable strategy for termination of cattle, regardless of the diet utilized. However, it is important to emphasize that one cannot evaluate the feedlot activity separately. In the global context of the rural company, it promotes live weight gain per hectare, which can elevate the profitability of the activity and the working capital.

The utilization of soybean in the diet for feedlot animals implied lower total gross margin when compared with cottonseed, which entails decrease in the profitability of confining animals, considering the prices practiced in the state of Minas Gerais in 2009. Whereas the ton of soy

Table 5 - Economic evaluation of steers fed different lipid sources in the feedlot (in the first semester of 2009)

\begin{tabular}{|c|c|c|c|c|}
\hline Item & SB & SBE & CS & CSE \\
\hline Cost with feeding/animal/day (R\$) & 4.48 & 4.63 & 3.59 & 3.74 \\
\hline Cost with supplementation of vitamin E (R\$/day) & 0 & 0.15 & 0 & 0.15 \\
\hline Days in feedlot & 84 & 84 & 84 & 84 \\
\hline Total cost with feeding/animal ( $\mathrm{R} \$$ in 84 days) & 376.32 & 388.92 & 301.56 & 314.10 \\
\hline Total cost/animal (R\$) & 432.55 & 447.03 & 346.62 & 361.10 \\
\hline Total cost/arroba $(\mathrm{R} \$)^{1}$ & 111.20 & 113.75 & 84.54 & 94.28 \\
\hline Average daily weight gain (kg/animal/day) & 1.39 & 1.42 & 1.50 & 1.40 \\
\hline Total average weight gain (kg/animal) & 116.76 & 119.28 & 126 & 117.6 \\
\hline Carcass yield (\%) & 55.1 & 55.8 & 53.8 & 54.6 \\
\hline Carcass weight gain (arroba) & 4.28 & 4.44 & 4.52 & 4.28 \\
\hline Price received per arroba $(\mathrm{R} \$)^{1}$ & 77.00 & 77.00 & 77.00 & 77.00 \\
\hline Total gross revenue ( $\mathrm{R} \$$ ) & 329.56 & 341.88 & 348.04 & 329.56 \\
\hline Estimated weight gain on pasture ( $\mathrm{kg} /$ animal/day) & 0.6 & 0.6 & 0.6 & 0.6 \\
\hline Time necessary to gain, on pasture, the same weight reached in feedlot (days) & 194.6 & 198.8 & 210 & 196 \\
\hline Time necessary to gain, on pasture, the same weight reached in feedlot (months) & 6.50 & 6.60 & 7.0 & 6.50 \\
\hline Pasture lease (R\$/animal/month) & 25.00 & 25.00 & 25.00 & 25.00 \\
\hline Gross margin with carcass sale ( $\mathrm{R} \$ /$ animal) & -102.99 & -105.15 & 1.42 & -31.54 \\
\hline Total gross margin (pasture lease + carcass sale) & 59.17 & 60.51 & 176.42 & 131.79 \\
\hline
\end{tabular}

SB - concentrate containing soybean; SBE - SB + Vitamin E; CS - concentrate containing cottonseed; CSE - CS + Vitamin E.; NDF - neutral detergent fiber; NFC - nonfibrous carbohydrates; TDN - total digestible nutrients.

1 arroba $=15 \mathrm{~kg}$. 
presented cost of $\mathrm{R} \$ 747.00$, the ton of cottonseed presented much lower value: $\mathrm{R} \$ 300.00$. Therefore, it is clear that the utilization of alternative feedstuffs is of paramount importance to reduction in the production cost.

In view of the results obtained, it can be seen that feedlot, as an exclusive activity, did not present profitability, which can be verified through the total gross revenue originated from the arrobas produced in feedlot, in which the price received per arroba was inferior to the total cost of feedlot.

Considering that in pasture regimens with supplementation of $0.5 \% \mathrm{LW}$ animals subjected to feedlot would gain $0.6 \mathrm{~kg} / \mathrm{day}$, about 194 to 210 more days would be necessary for them to achieve the weight reached at finishing in feedlot. The clearance of pastures, therefore, corresponds to an important advantage to the rural entrepreneur, who chooses for the fattening in feedlot.

The activity of feedlot presents profitability in a direct form to the farmer, in very specific situations, as the literature has reported. According to Lanna \& Almeida (2005), among the main benefits of feedlot, these can be cited: clearance of pastures to other animal categories, increasing the stocking rate of the property and reducing the risks, for enabling reserving of forage. In some situations, the increase in meat production can reach $300 \%$ per hectare. Besides, some other important benefits of feedlot fattening would be: elevation in the return over the capital invested, anticipation of revenues and of the working capital, slaughter of younger cattle/cattle with carcasses with greater fat cover, and reduction in the variability of meat produced both of finishing and age. One of the biggest problems of the beef productive chain is the inconstancy of the quality of the end product, which can be attenuated through the utilization of feedlot fattening. Besides, the utilization of feedlot can increase the efficiency of the slaughterhouse industry, as a consequence of the possibility of increasing weight at slaughter.

\section{Conclusions}

Supplementation with vitamin E does not present positive effects on performance of feedlot cattle. In addition, the utilization of soybean or cottonseed promotes similar performance. However, the utilization of cottonseed may reduce carcass yield and backfat thickness. The lipid sources utilized do not present influence on meat tenderness. The utilization of cottonseed in replace of soybean can bring increase to the profitability of rearing cattle in feedlot because of the lower cost.

\section{References}

AMERICAN MEAT SCIENCE ASSOCIATION - AMASA. Guidelines for cooking sensory evaluation of meat. Chicago: American Meat Science Association, National Live Stock and Meat Board, 1978. 24p.

ANDRADE, P.L.; BRESSAN, M.C.; GAMA, L.T. et al. Qualidade da carne maturada de bovines Red Norte e Nelore. Revista Brasileira de Zootecnia, v.39, n.8, p.1791-1800, 2010.

COMMONWEALTH SCIENTIFIC AND INDUSTRIAL RESEARCH ORGANIZATION - CSIRO. Feeding standards for Australian livestock - ruminants. Victoria: Australia Agricultural Council, 1990. 266p.

COSTA, Q.P.B.; WECHSLER, F.S.; COSTA, D.P.B. et al . Desempenho e características da carcaça de bovinos alimentados com dietas com caroço de algodão. Arquivo Brasileiro de Medicina Veterinária e Zootecnia, v.63, p.729-735, 2011.

CRANSTON, J.J.; RIVERA, J.D.; GALYEAN, M.L. et al. Effects of feeding whole cottonseed and cottonseed products on performance and carcass characteristics of finishing beef cattle. Journal of Animal Science, v.84, n.9, p.2186-2194, 2006

GOERING, H.K.; VAN SOEST, J.P. Forage fiber analysis (apparatus reagents, procedure, and some applications). Washington, D.C.: Agricultural Handbook, ARS, USDA, 1970. 379p.

GUNN, P.J.; WEAVER, A.D.; LEMENAGER, R.P. et al. Effects of dietary fat and crude protein on feedlot performance, carcass characteristics, and meat quality in finishing steers fed differing levels of dried distillers grains with soluble. Journal of Animal Science, v.87, n.4, p.2882-2890, 2009

HILL, G.M.; WILLIAMS, S.E. Vitamin E in beef nutrition and meat quality. In: MINNESOTA NUTRITION CONFERENCE, 54., 1993, Bloomington. Proceedings.... Bloomington: University of Minnesota, 1993. p.197.

HUERTA-LEIDENZ, N.O.; CROSS, H.R.; SAVELI, J.W. et al. Comparison of the fatty acid composition of subcutaneous adipose tissue from mature Brahman and Hereford cows. Journal of Animal Science, v.71, p.625-630, 1993.

HUFF-LONERGAN, E.; LONERGAN, S.M. Review. Mechanisms of water-holding capacity of meat: The role of postmortem biochemical and structural changes. Meat Science, v.71, p.194-204, 2005.

JOHNSON, D.D.; HUFFMAN, R.D.; WILLIAMS, S.E. et al. Effect of percentage Brahman and Angus breeding age-season of feeding and slaughter end point on meat palatability and muscle characteristics. Journal of Animal Science, v.68, p.1980-1986, 1990.

KOOHMARAIE, M. Muscle proteinases and meat aging. Meat Science, v.36, p.93-104, 1994

KOOHMARAIE, M.; KENT, M.P.; SHACKEIFORD, S.D. et al. Meat tenderness and muscle growth: is there any relationship? Meat Science, v.62, p.345-352, 2003.

LANNA, D.P.D.; ALMEIDA, R. A terminação de bovinos em confinamento. Visão Agrícola, v.3, p.55-58, 2005.

LOPES, L.S.; LADEIRA, M.M.; MACHADO NETO, O.R. et al. Viabilidade econômica da terminação de novilhos Nelore e Red Norte em confinamento na região de Lavras-MG. Ciência e Agrotecnologia, v.35, p.774-780, 2011.

LOVEDAY, H.D.; DIKEMAN, M.E.; HUNT, M.C. Adipose tissue chemical composition and carcass traits related to bovine carcass composition. Journal of Animal Science, v.47, n.11, p.606-613, 1980

MILLEN, D.D. A snapshot of management practices and nutritional recommendations used by feedlot nutritionists in Brazil. Journal of Animal Science, v.87, p.3427-3439, 2009.

NATIONAL RESEARCH COUNCIL - NRC. Nutrient requirements of beef cattle. 7.ed. Washington, D.C.: National Academy Press, 1996. 244p. 
NATIONAL RESEARCH COUNCIL - NRC. Nutrient requirements of dairy cattle. 7 rev. ed. Washington, D.C.: National Academic Press, 2001. 287p.

NEMEC, M. Effect of supplementing gilts' diets with different levels of vitamin $\mathrm{E}$ and different fats on the humoral and cellular immunity of gilts and their progeny. Journal of Animal Science, v.72, n.6, p.665-675, 1994.

OLIVEIRA, D.M. Características de carcaça e qualidade da carne de novilhos zebuínos recebendo diferentes grãos de oleaginosas. 2010. 107f. Tese (Doutorado em Zootecnia) Universidade Federal de Lavras, Lavras.

PEPLOWSKI, M.A; MAHAN, D.C.; MURRAY, E.A. Effect of dietary and injectable vitamin $\mathrm{E}$ and selenium in weanling swine antigenically challenged with sheep red blood cells. Journal of Animal Science, v.51, n.6, p.344-351, 1980.

PESCE, D.M.C. Efeito da dieta contendo caroço de algodão no desempenho, características quantitativas da carcaça e qualitativas da carne de novilhos Nelore confinados. 2008. 138f. Tese (Doutorado em Zootecnia) - Universidade de São Paulo, Pirassununga.

REID, J.T.; WELLINGTON, G.H.; DUNN, H.O. Some relationships among the major chemical components of the bovine body and their application to nutritional investigations. Journal of Dairy Science, v.38, p.1344-1352, 1955.

REDDY, J.K.; GOEL, S.K.; NEMALI, M.R. et al. Transcriptional regulation of peroxisomal fatty acyl-CoA oxidase and cnoylCoA hydratase/3-hydroxyacyl-CoA dehydrogenase in rat liver by peroxisome proliferator. Proceedings of National Academy Sciences, v.83, n.9, p.1344-1360, 1986.

RESTLE, J.; PASCOAL, L.L.; FATURI, C. et al. Efeito do grupo genético e da heterose nas características quantitativas da carcaça de vacas de descarte terminadas em confinamento. Revista Brasileira de Zootecnia, v.31, n.1, p.350-362, 2002.

SECRIST, D.S. Effects of vitamin $E$ on performance of feedlot cattle: a review. Stillwater: Oklahoma State University, 1995. 137p. (Report).

SHACKELFORD, S.D.; KOOHMARAIE, M.; CUNDIFF, L.V. et al. Heritabilities and phenotypic and genetic correlations for bovine post rigor calpastatin activity, intramuscular fat content, Warner-Bratzler shear force, retail product yield, and growth rate. Journal of Animal Science, v.72, n.4, p.857-863, 1991.

VALADARES FILHO, S.C.; PAULINO, P.V.R.; MAGALHAES, K.A. et al. Modelos nutricionais alternativos para otimização de renda na produção de bovinos de corte. In: ANAIS DO SIMPÓSIO DE PRODUÇÃO DE GADO DE CORTE. 1.ed. Rio Branco MG: Suprema Gráfica e Editora Ltda, 2002. v.1, p.197-254.

VAN SOEST, P.J.; ROBERTSON, J.B.; LEWIS, B.A. et al. Methods for dietary fiber, and nonstarch polysaccharides in relation to animal nutrition. Journal of Dairy Science, v.74, p.3583-3597, 1991.

VASCONCELOS, J.T.; GALYEAN, M.L. Nutritional recommendations of feedlot consulting nutritionists: The 2007 Texas Tech University survey. Journal of Animal Science, v.85, n.2 p.2772-2781, 2007.

VAZ, F.N.; RESTLE, J. Produção de carne com qualidade. In: RESTLE, J.; BRONDANI, I.L.; PASCOAL, L.L. et al. (Eds.) Produção intensiva com qualidade em bovinos de corte. Santa Maria: Universidade Federal de Santa Maria, 1999. p.104-119.

WHEELER, T.L.; KOOHMARAIE, M.; SHACKELFORD, S.D. Standardized Warner-Bratzler shear force procedures for meat tenderness measurement. Clay Center: Roman L. Hruska U. S. MARC. USDA, 1995. 7p. 